\title{
NUTRITIONAL EFFECTS OF HOUSEHOLD FOOD WASTES SUPPLEMENTATION IN SHEEP DIET
}

\author{
ELDOSOKY NASSEF*; WALIED ABDO**; ELSAYED HEGAZI", ABDELNASER BAKR* and \\ WAEL GODA ${ }^{* * *}$ \\ *Department of Nutrition and Clinical Nutrition, Faculty of Veterinary Medicine, Kafrelsheikh University 33516, Egypt. \\ ** Department of Pathology, Faculty of Veterinary Medicine, Kafrelsheikh University 33516, Egypt. \\ **** Department of Clinical Pathology, Faculty of Veterinary Medicine, Kafrelsheikh University 33516, Egypt. \\ Phone number: +2-047-323-1609; Fax number: +2-047-323-1311
}

Email: waliedsobhy@yahoo.com

Assiut University web-site: www.aun.edu.eg

\section{ABSTRACT}

Received at: 29/6/2015

Accepted: 29/7/2015
The present study aimed to assess the household food waste (HFW) as a substituted source of low cost feed for sheep. HFW was freshly collected, weighed, dried, ground and then chemically analyzed. On as-fed basis, HFW was used as an ingredient in the formulating balanced diet for lambs at varying levels of substitution $(0 \%, 15 \%$ and $30 \%)$. On dry matter (DM) basis, HFW contained moderate protein content $(14.72 \%)$, ether extract $(6.96 \%)$, non-fibrous carbohydrate $(47.39 \%)$, and ash $(10.98 \%)$. The growth performance and feed efficiency of lambs supplemented with 15 and $30 \%$ HFW-contained diets were similar to control animals. The effect of HFW on fasted live weight, carcass weight, dressing percentages and meat chemical composition was also within the range of lambs feed on normal diet. Histopathologically, mosaic appearance of glycogen infiltration which may support the fattening effect. Unless, the oval cell proliferation associated with higher serum levels of GGT enzyme in 30\% HFW-containing diet, which might be attributed to higher residue levels of iron in HFW. Therefore, HFW might be incorporated in lower concentration in lamb diet.

Key words: Household food waste; Growth performance; Digestibility; Sheep.

\section{INTRODUCTION}

Food waste defined as any food not consumed by humans, which can be generated at any level within the food chain, farms, processing plants, manufacturers, commercial establishments and households Okazaki et al. (2008). It includes vegetables, fruit, animal by-products and cereals' wastes. So far, the exact data on the amount of food waste are relatively sparse. An estimate depending on energy calculation indicated that the rate of food waste exceeds $40 \%$ in the United States Hall et al. (2009). In Japan, food waste is about twenty million tons per year, 3 and $5 \%$ were used as fertilizer and feed respectively Kawashima., (2004). Recently, the term of ecofeed, safety usage of the recycled food waste has been motivated upon economic and economic and environmental considerations Sugiura et al. (2009).

Food wastes usually have high energy and/or protein contents, which can provide competitive alternatives to more traditional energy or protein sources Westendorf., (2000). Substitution of imported commercial feeds with food waste can save energy in transportation, reduce the environmental impact of waste burning or land filling and decrease animal production costs Cao et al. (2009). Moreover, food waste has high nutritive value that can be used in animal nutrition without health problems Summers et al. (1980). On the other aspect, incineration of different food waste induces emission of global warming gases and toxic substances such as dioxin and heavy metals Kawashima (2004). Furthermore, the disposal of waste to land fill was incriminated in environmental pollution through release of methane, which is a powerful green house gas Griffin et al. (2009). Food waste is composed of highly complex molecules that could be used as raw materials or a portion of their contents could be extracted Oreopoulou et al. (2007).

The feed cost considers the major section of the total animal production costs. Therefore, the substitution of conventional feed stuffs by HFW may lead to a significant reduction in the cost of animal feed and subsequently the ultimate derived products. Therefore, the objective behind recycling HFW into animal product is to achieve the same level of performance while decreasing the cost of production and maintaining a more sustainable agriculture system Normand (1996). 
In Egypt, there are large number of sheep and goat feed on HFW especially in rural areas near cities. Therefore, the current study aimed to study the possible supplementation of HFW in lamb diet based on animal growth performance and clinicopathological parameters of metabolic organs.

\section{MATERIALS and METHODS}

1- Collection, quantitation and processing of HFW House food wastes were daily collected from different houses and restaurants in Kafrelsheikh city from the period of the $1^{\text {st }}$ of February to $1^{\text {st }}$ of May 2010. Then, sorting, drying and grinding were done in the Faculty of Veterinary Medicine, Kafrelsheikh University. The number of participants of each family was recorded to quantify HFW per person on a daily basis.

\section{2- Animals and diets}

The study was carried out on 15 Barki male lambs with average body weight $(22.98 \pm 3.25) \mathrm{kg}$, housed in individual straw-bedded pen. Lambs were divided into three groups of five animals per each, based on the percentage of HFW incorporated in the animal rations $(0 \%, 15 \%$ and $30 \%)$. The lambs were underwent a fattening period of 8 weeks preceded by 10 days adaptation period. All procedures of the study were done according to the guidelines of Kafrelsheikh University and the Council Directive 86/609/EEC of European Communities for animals welfare for experimental and scientific purposes Communities (1986).

Diets were formulated to meet the nutrient requirements for lambs according to the feeding standards NRC (1985). Diets were formulated to contain different feed ingredients including alfalfa hay, Egyptian clover straw, soybean meal 44\%, yellow corn grain, wheat bran, limestone, and salt. The chemical composition of the feedstuffs is illustrated in Table1. The diets were formulated (Table 2) to contain $0 \%, 15 \%$ and $30 \%$ of $\mathrm{HFW}$ instead of wheat bran (on as-fed basis). The ingredients of each diet were ground, thoroughly mixed and pressed into pellets of six mm diameter to decrease selective feeding.

Assessment offeeding amount, daily gain and Cost Feed intake was recorded daily, and DM content was determined to calculate individual voluntary dry matter in takes (DMI). To calculate average daily gain and feed conversion ratio, the lambs were weighed biweekly. Representative samples of the diets and feed ingredients were collected at regular intervals and pooled for subsequent analysis. Finally, an estimate of the feeding cost per kilogram of body weight gain was recorded.

\section{3- Digestibility trial}

Lambs were housed individually in metabolism crates to evaluate nutrient digestibility. Lambs were fed at
$90 \%$ of the voluntary intake determined during the growth trial. Daily fecal samples were collected, weighed and recorded, and then $10 \%$ were kept for subsequent analyses. Fecal samples were dried at $55^{\circ} \mathrm{C}$, in a forced-air oven to reach a constant weight, then ground to pass $1 \mathrm{~mm}$ screen (Cyclotec 1093, Foss Sweden), and then kept for further analysis. Refused feed samples were collected every $24 \mathrm{hrs}$ in separate plastic bags for each lamb. Offered and refused feeds were weighed and sampled for each lamb daily. These sub-samples were further mixed into a composite sample by animal, before grinding. Representative samples of feed, refusals and feces were stored for further analysis. These samples were analyzed for DM, ash, crude protein (CP), ether extract (EE), acid detergent fiber (ADF), and neutral detergent fiber (NDF) AOAC., (2005).

\section{4- Carcass characteristics and meat chemical composition}

The lambs were slaughtered at the Center of Agriculture and Production facility at Kafrelsheikh University Abdullah et al. (1998). Approximately 18 hrs after the last feeding, the fasted live weight and hot carcass weight after slaughter were recorded. Dressing percentage was calculated as the percentages of hot carcass weight/fasted live weight. Liver, kidney and heart were excised and weighed. Organ weights were expressed as absolute organ weight $(\mathrm{kg})$ and relative to body weight and carcass weight (\%). The longissimus dorsi muscle was excised, prepared by removal of visible fat and epimysium before mincing in a blender and kept at $25{ }^{\circ} \mathrm{C}$ until analysis Boccard et al. (1981). Then, chemical analyses of moisture, $\mathrm{CP}, \mathrm{EE}$ and ash were carried out according toAOAC., (2005).

\section{5- Chemical analysis}

Samples from feeds, whole diets and dried fecal matter were collected and grounded to pass $1 \mathrm{~mm}$ screen (Cyclotec1093, Foss Sweden). Samples were analyzed for DM $\left(100^{\circ} \mathrm{C}\right.$ in air-forced oven to constant weight; method 934.01), ash $\left(600^{\circ} \mathrm{C}\right.$ in muffle furnace for $2 \mathrm{~h}$; method 942.05), EE (Soxhlet procedure; method 2003.05) and CP (Kjeldahl procedure; method 2001.11) AOAC., (2005). NDF and $\mathrm{ADF}$ were determined using $\mathrm{ANKOM}^{2000}$ fiber analyzer apparatus (ANKOM Technology Cooperation, Fairport, NY, USA). NDF analysis was performed using sodium sulfite and alpha amylase (heat stable) and expressed with residual ash content. Non-fibrous carbohydrates (NFC) content was estimated using the formula: $\mathrm{NFC}=\mathrm{DM}-(\mathrm{CP}+\mathrm{EE}$ + ash + NDF). Total digestible nutrients (TDN) based on nutrient analyses were estimated (NRC, 1985). Mineral composition was analyzed using atomic absorption spectrophotometer (V-630, Jasco, Japan), (AOAC, 2005). The total aflatoxin content in the feeds and whole diet was determined according to the 991.31 method using monoclonal antibody columns 
for aflatoxin B1 and B2 (VICAM Science Technology, Watertown, MA,USA).

\section{6- Serum biochemical analysis of liver and kidney functions}

Blood samples were collected from each lamb by jugular vein puncture. The blood samples allowed to coagulate at room temperature for $3 \mathrm{hrs}$, centrifuged at $3000 \mathrm{rpm}$ for $15 \mathrm{~min}$, sera were collected in Eppendorf vials and kept at $-20{ }^{\circ} \mathrm{C}$ for later analysis. Serum AST, ALT and GGT enzyme activities as well as the concentration of Total proteins and the level of creatinine were evaluated using commercially available standard diagnostic kits (Stanbio Laboratory Boerne, USA).

\section{7- Histopathological Examination}

Livers and kidneys were fixed in $10 \%$ neutral-buffered formalin. Then specimens were then dehydrated in a graded series of ethanol, cleared in xylene and embedded in paraffin wax. Next, the paraffin-embedded specimens were sectioned into $4-\mu \mathrm{m}$ samples for hematoxylin and eosin staining (Sigma-Aldrich Chemie GmbH).

\section{8- Statistical analysis}

All results were subjected to ANOVA using JMP 10 statistical analysis soft ware package (SAS, 2012). Dietary treatments were the main source of variance. Differences between means were tested for significance using Dennett's Least Significant Difference procedure (LSD) at 0.05 level of probability.

\section{RESULTS}

The total HFW was 18.58 tones collected from 600 participants within three months in Kafrelsheikh city (Egypt), representing $0.344 \pm 0.184 \mathrm{kgper}$ person per day.

On DM basis, the chemical composition of HFW has CP (14.72\%), starch (32.47\%), EE (6.96\%), and ash (10.98\%). Moreover, higher concentrations of calcium, phosphorus, sodium and chlorine were obtained (Table 1). Furthermore, chemical composition of the different tested diets is illustrated in Table 3.

The results of growth, feed intake and feed conversion ratio are presented in Table 4 . There was no statistically significant difference in the final liveweight between the groups. The average daily gains were 188, 193 and $218 \mathrm{~g}$ /day in $0 \%, 15 \%$ and $30 \%$ HFW supplemented groups respectively. Feed consumption of lambs fed on diets containing HFW was similar to those control animals.

All groups showed a nearly similar feed conversion ratio, mean while the cost of production was lower in lambs fed on $30 \% \mathrm{HFW}$ diet as compared to $0 \%$ fed lambs $(P<0.05)$. Also, the price of HFW, including the price of transportation and processing, was about $31 \%$ of the wheat bran price. In addition the replacement of wheat bran by HFW at 15 and $30 \%$ reduced the cost by 12 and $22 \%$ respectively.

Digestion coefficients of DM, CP, EE, NDF, ADF and NFC of the control diet and diets containing HFW are summarized in Table 5. There was no significant difference among various groups in the mean digestibility coefficients of DM, CP, NDF, ADF and NFC. EE digestibility was tended to be higher in lambs fed diets containing $15 \%$ and $30 \%$ HFW than those fed on control diet.

Fasting live weight, hot carcass weight, dressing percentages, organs weight and relative organs weight and carcass weight are shown in Table 6. No differences were observed in such parameters among the different animal groups. Chemical composition of lamb meat is shown in Table 7. The moisture, protein, ash and fat content were also similar within the different groups.

Total proteins concentration, creatinine level, AST, ALT, and GGT serum enzymatic activities of lambs are illustrated in Table 8. Lambs fed on HFW at $15 \%$ demonstrated increase GGT serum level, which was significantly increased with $30 \%$ supplementation of HFW. The other parameters were elevated with high HFW, but it was still within the normal limits.

Histopathologically, livers and kidneys samples from each group are shown in (Figs 1 and 2). Livers of sheep feed on normal diet were within the normal histological features (Fig1A). The liver of sheep supplemented with food containing HWF at $15 \%$ revealed enlarged pale hepatocytes of centrolobular and midzonal areas compressing the outer periportal area, showing a mosaic-like pattern consistent with glycogen storage. Also, there was occasionally minimal periportal mononuclear cells infiltration (Fig1B). One animal of this group showed periportal mononuclear cells infiltration and also round to oval cells with little basophilic cytoplasm, and round or oval nucleus was with light clear membrane and clear small nucleolus consistent with oval cells (Fig 1C). Regarding animals feed on formulated diet-containing $30 \% \mathrm{HFW}$, one of them showed normal liver with minimal periportal inflammatory cells infiltration. While the other animals demonstrated marked periportal mononuclear cells inflammatory cells infiltration and oval cells proliferation (Fig1D). Moreover, multifocal areas of single cell to focal hepatic necrosis were noticed.

The kidneys of different group were within the normal limits, however, the animal supplemented with $30 \%$ of HWF showed mild degeneration of renal tubular epithelium associated with hyaline cast (Fig. 2). 

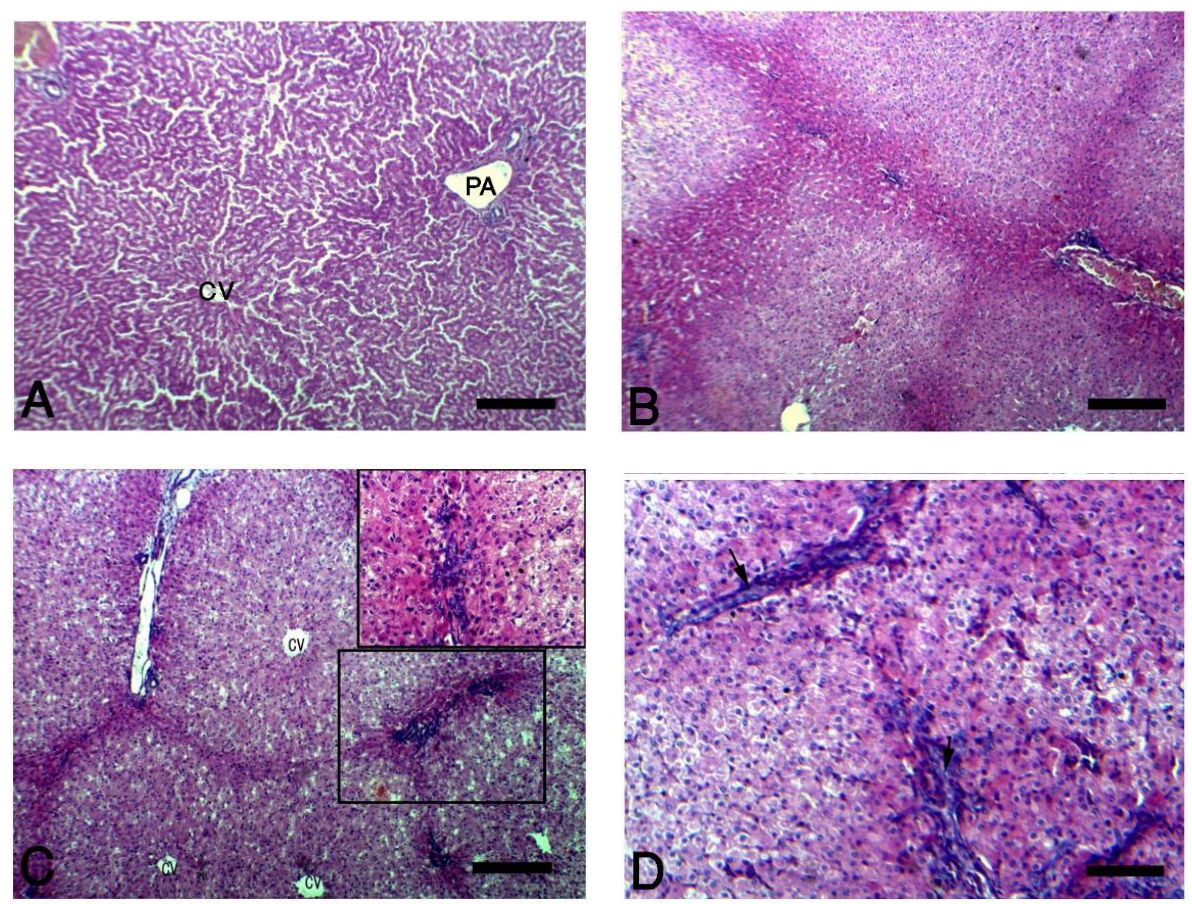

Figure 1: Liver sections of sheep feed on normal diet, 15 and 30\% HFW contained diets. (A) photomicrograph of normal liver section of sheep feed on normal diet, $\mathrm{H} \& \mathrm{E}$, bar $=100 \mu \mathrm{m}$. (B) photomicrograph of liver section of sheep feed on normal diet contained $15 \%$ of HFW showing mosaic like appearance with mild periportal leucocytic infiltration H\&E, bar=100 $\mu \mathrm{m}$. (C) Photomicrograph of liver section of sheep feed on normal diet contained 15\% HFW showing periportal oval cell proliferation H\&E, bar=100 $\mu \mathrm{m}$. Inset showing periportal oval cell proliferation, $\mathbf{C V}$ central vein, H\&E, bar=100 $\mu \mathrm{m}$. (D) Photomicrograph of liver section of sheep feed on normal diet contained 30\% HFW showing marked periportal oval cell proliferation (arrows), H\&E, bar=50 $\mu \mathrm{m}$.
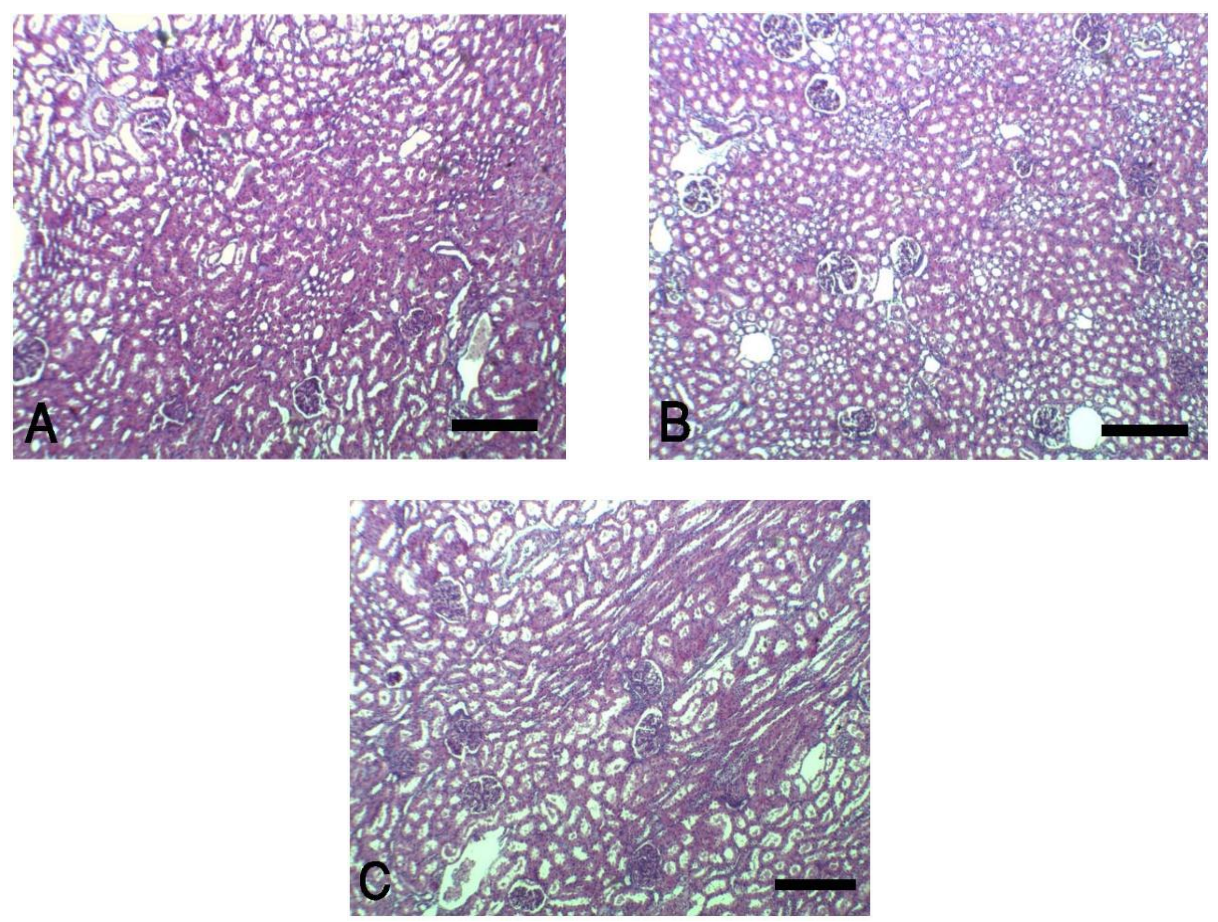

Figure 2: Kidney sections of sheep feed on normal diet, 15 and 30\% HFW contained diets. (A) kidney of sheep feed on normal diet, H\&E, bar $=100 \mu \mathrm{m}$. (B) kidney of sheep feed on normal diet contained $15 \%$ of HFW were within normal H\&E, bar $=100 \mu \mathrm{m}$. (C) kidney of sheep feed on normal diet contained $30 \%$ HFW showing hyaline cast $\mathrm{H} \& \mathrm{E}$, bar $=100 \mu \mathrm{m}$. 
$\underline{\text { Assiut Vet. Med. J. Vol. } 61 \text { No. } 146 \text { July } 2015}$

Table 1: Chemical composition of the feedstuffs (on DM basis).

\begin{tabular}{|c|c|c|c|c|c|c|}
\hline Nutrients & $\mathrm{HFW}^{\mathrm{A}}$ & Wheat bran & Corn grains & Soybean meal & Alfalfa hay & $\mathrm{ECS}^{\mathrm{B}}$ \\
\hline Moisture (\%) & 10.51 & 10.9 & 11.9 & 10.9 & 6.82 & 5.55 \\
\hline Organic matter $(\%)$ & 89.02 & 93.7 & 98.5 & 93.4 & 86.56 & 85.91 \\
\hline $\operatorname{DM}(\%)$ & 89.49 & 89.1 & 88.1 & 89.1 & 93.18 & 94.45 \\
\hline Crude protein $(\%)$ & 14.72 & 17.3 & 9.1 & 49.9 & 20.0 & 7.0 \\
\hline Total digestible nutrient ${ }^{\mathrm{C}}(\%)$ & 67.35 & 71.44 & 88.68 & 80.0 & 56.91 & 44.3 \\
\hline Neutral detergent Fiber (\%) & 19.95 & 42.5 & 9.5 & 14.9 & 36.49 & 70.0 \\
\hline Acid detergent Fiber $(\%)$ & 11.03 & 15.5 & 3.4 & 10.0 & 28.26 & 50.0 \\
\hline Non fibrous carbohydrate $(\%)$ & 47.39 & 29.6 & 75.7 & 27.0 & 28.07 & 8.07 \\
\hline Starch $(\%)$ & 32.47 & 22.5 & 72.1 & 1.7 & 1.8 & 0.0 \\
\hline Ether extract $(\%)$ & 6.96 & 4.3 & 4.2 & 1.6 & 2.0 & 0.84 \\
\hline Ash (\%) & 10.98 & 6.3 & 1.5 & 6.6 & 13.44 & 14.09 \\
\hline Calcium (\%) & 1.68 & 0.13 & 0.04 & 0.4 & 1.47 & 0.31 \\
\hline Phosphorus (\%) & 0.58 & 1.18 & 0.3 & 0.71 & 0.28 & 0.1 \\
\hline Sodium (\%) & 1.17 & 0.04 & 0.02 & 0.04 & 0.1 & 0.12 \\
\hline Potassium (\%) & 0.96 & 1.32 & 0.42 & 2.22 & 2.37 & 1.51 \\
\hline Chlorine (\%) & 1.81 & 0.16 & 0.08 & 0.13 & 0.65 & 0.6 \\
\hline Cobalt (ppm) & 0.0 & 0.0 & 0.0 & 0.0 & 0.31 & 0.0 \\
\hline Copper (ppm) & 13.18 & 11.0 & 3.0 & 22.0 & 9.0 & 6.0 \\
\hline Iron (ppm) & 756.6 & 157.0 & 54.0 & 185.0 & 619.0 & 172.0 \\
\hline Manganese (ppm) & 24.06 & 122.0 & 11.0 & 35.0 & 44.0 & 67.0 \\
\hline Zinc (ppm) & 41.56 & 85.0 & 27.0 & 57.0 & 28.0 & 16.0 \\
\hline Total aflatoxins (ppb) & 1.1 & 1.3 & 1.0 & 1.1 & 1.0 & 1.0 \\
\hline
\end{tabular}

${ }^{\mathrm{A}} \mathrm{HFW}$, household food waste; ${ }^{\mathrm{B}} \mathrm{ECS}$, Egyptian clover straw; ${ }^{\mathrm{C}}$ value of total digestible nutrient was determined according to NRC (1985).

Table 2: Ingredient composition of the experimental diets (on as-fed basis).

\begin{tabular}{cccc}
\hline \multirow{2}{*}{ Ingredients $(\%)$} & \multicolumn{3}{c}{ Dietary treatments } \\
\cline { 2 - 4 } & $0 \%$ HFW & $15 \%$ HFW & $30 \%$ HFW \\
\hline Alfalfa hay & 15.0 & 16.0 & 16.0 \\
\hline Egyptian clover straw & 13.0 & 15.0 & 11.5 \\
\hline Soybean meal 44\% & 11.0 & 11.0 & 25.0 \\
\hline Corn grains, ground & 29.0 & 26.5 & 00 \\
\hline Wheat bran & 30.0 & 15.0 & 30.0 \\
\hline HFW & 00 & 15.0 & 1.0 \\
\hline Limestone & 1.5 & 1.2 & 0.0 \\
\hline Common salt & 0.5 & 0.3 & \\
\hline
\end{tabular}

${ }^{\mathrm{A}} \mathrm{HFW}$, household food waste. 
Assiut Vet. Med. J. Vol. 61 No. 146 July 2015

Table 3: Chemical composition of the experimental diets (on DM basis)

\begin{tabular}{|c|c|c|c|}
\hline \multirow[t]{2}{*}{ Nutrients } & \multicolumn{3}{|c|}{ Dietary treatments } \\
\hline & $0 \% \mathrm{HFW}^{\mathrm{A}}$ & $15 \% \mathrm{HFW}$ & $30 \% \mathrm{HFW}$ \\
\hline $\mathrm{DM}(\%)$ & 91.36 & 91.27 & 90.45 \\
\hline Organic matter (\%) & 90.84 & 90.22 & 88.43 \\
\hline Crude protein $(\%)$ & 16.16 & 16.61 & 17.04 \\
\hline Ether extract (\%) & 2.82 & 3.59 & 4.22 \\
\hline Neutral detergent fiber $(\%)$ & 31.58 & 30.52 & 26.66 \\
\hline Acid detergent fiber $(\%)$ & 18.13 & 18.45 & 18.37 \\
\hline $\operatorname{Ash}(\%)$ & 8.37 & 8.93 & 10.47 \\
\hline Non fibrous carbohydrate (\%) & 41.07 & 40.34 & 41.61 \\
\hline Total digestible nutrient ${ }^{\mathrm{B}}(\%)$ & 69.55 & 70.53 & 71.33 \\
\hline Calcium (\%) & 0.91 & 1.05 & 1.31 \\
\hline Phosphorus (\%) & 0.48 & 0.43 & 0.39 \\
\hline Sodium $(\%)$ & 0.59 & 0.69 & 0.88 \\
\hline Potassium (\%) & 1.33 & 1.33 & 1.4 \\
\hline Iron $(\mathrm{mg} / \mathrm{kg})$ & 476.33 & 405.84 & 771.91 \\
\hline Copper (mg/kg) & 12.35 & 33.02 & 20.57 \\
\hline Manganese $(\mathrm{mg} / \mathrm{kg})$ & 48.05 & 42.65 & 27.42 \\
\hline Zinc $(\mathrm{mg} / \mathrm{kg})$ & 50.79 & 63.28 & 46.62 \\
\hline Total aflatoxins (ppb) & 1.0 & 1.0 & 1.0 \\
\hline
\end{tabular}

${ }^{\mathrm{A}} \mathrm{HFW}$, household food waste; ${ }^{\mathrm{B}}$ value of total digestible nutrient was determined according to (NRC 1985) sheep equation.

Table 4: Growth performance and feeding cost.

\begin{tabular}{cccc}
\hline Parameters & \multicolumn{3}{c}{ Dietary treatments } \\
\cline { 2 - 4 } & $0 \% \mathrm{HFW}$ & $15 \% \mathrm{HFW}$ & $30 \% \mathrm{HFW}^{\mathrm{A}}$ \\
\hline Initial body weight $(\mathrm{kg})$ & $22.19 \pm 1.40$ & $23.14 \pm 1.33$ & $22.53 \pm 1.30$ \\
\hline Final body weight $(\mathrm{kg})$ & $33.07 \pm 3.11$ & $33.65 \pm 2.45$ & $31.17 \pm 2.08$ \\
\hline Body weight gain $(\mathrm{kg})$ & $10.88 \pm 2.94$ & $10.51 \pm 1.30$ & $8.64 \pm 1.95$ \\
\hline Average daily gain $(\mathrm{kg})$ & $0.20 \pm 0.05$ & $0.19 \pm 0.02$ & $0.16 \pm 0.04$ \\
\hline Feed consumed $(\mathrm{kg} /$ day) & $1.27 \pm 0.17$ & $1.29 \pm 0.21$ & $1.10 \pm 0.25$ \\
\hline Feed conversion ratio & $7.17 \pm 3.05$ & $6.86 \pm 0.97$ & $7.43 \pm 2.52$ \\
\hline Cost/kg gain (EGP) & $9.86 \pm 0.38$ & $6.32 \pm 1.28^{\mathrm{a}}$ & $5.54 \pm 0.74^{\mathrm{a}}$
\end{tabular}

Data expressed as mean $\pm \mathrm{SD}$, standard deviation, ${ }^{\mathrm{A}} \mathrm{HFW}$, household food waste; superscript letter (a) are significantly different at $(P<0.05)$.

Table 5: Nutrient digestibility of Barki lambs fed diets containing HFW.

\begin{tabular}{cccc}
\hline \multicolumn{3}{c}{ Dietary treatments } \\
\hline Digestibility $(\%)$ & $0 \% \mathrm{HFW}^{\mathrm{B}}$ & $15 \% \mathrm{HFW}$ & $30 \% \mathrm{HFW}$ \\
\hline DM & $58.5 \pm 1.20$ & $59.25 \pm 1.87$ & $61.25 \pm 2.14$ \\
\hline Crude protein & $75.75 \pm 2.15$ & $73.25 \pm 1.46$ & $71.75 \pm 2.12$ \\
\hline Ether extract & $58.07 \pm 4.32$ & $70.92 \pm 3.48^{\mathrm{a}}$ & $74.5 \pm 5.18^{\mathrm{a}}$ \\
\hline Neutral detergent fiber & $51.57 \pm 0.78$ & $52.28 \pm 1.10$ & $56.7 \pm 3.22$ \\
\hline Acid detergent fiber & $33.37 \pm 2.12$ & $33.06 \pm 3.15$ & $31.21 \pm 3.54$ \\
\hline Non fibrous carbohydrate & $88.49 \pm 4.65$ & $87.35 \pm 3.16$ & $86.33 \pm 4.12$ \\
\hline Total digestible nutrients & $69.67 \pm 3.73$ & $70.35 \pm 2.85$ & $71.98 \pm 3.98$ \\
\hline
\end{tabular}

Data expressed as mean $\pm \mathrm{SD}$, standard deviation, ${ }^{\mathrm{A}} \mathrm{HFW}$, household food waste; superscript letter (a) are significantly different at $(P<0.05)$. 
Assiut Vet. Med. J. Vol. 61 No. 146 July 2015

Table 6: Carcass traits and organs weight.

\begin{tabular}{lccc}
\hline Parameters & \multicolumn{3}{c}{ Dietary treatments } \\
\hline & $0 \% \mathrm{HFW}^{\mathrm{B}}$ & $15 \% \mathrm{HFW}$ & $30 \% \mathrm{HFW}$ \\
\hline Carcass weight $(\mathrm{kg})$ & $18.55 \pm 1.01$ & $18.67 \pm 0.89$ & $17.23 \pm 0.55$ \\
\hline Dressing $(\%)$ & $56.27 \pm 2.94$ & $55.58 \pm 2.04$ & $55.71 \pm 2.90$ \\
\hline Liver weight $(\mathrm{kg})$ & $0.64 \pm 0.04$ & $0.63 \pm 0.07$ & $0.64 \pm 0.04$ \\
\hline Kidney weight $(\mathrm{kg})$ & $0.16 \pm 0.03$ & $0.14 \pm 0.06$ & $0.18 \pm 0.02$ \\
\hline Heart weight $(\mathrm{kg})$ & $0.12 \pm 0.02$ & $0.14 \pm 0.03$ & $0.12 \pm 0.03$ \\
\hline
\end{tabular}

Data expressed as mean $\pm \mathrm{SD}$, standard deviation, HFW, household food waste $(P>0.05)$.

Table 7 :Chemical analysis of the longissimus dorsi muscle (\% wet basis).

\begin{tabular}{lccc}
\hline Parameters & \multicolumn{3}{c}{ Dietary treatments } \\
\hline & $0 \% \mathrm{HFW}^{\mathrm{B}}$ & $15 \% \mathrm{HFW}$ & $30 \% \mathrm{HFW}$ \\
\hline Moisture & $73.93 \pm 5.32$ & $74.2 \pm 7.25$ & $73.93 \pm 4.26$ \\
\hline $\mathrm{DM}$ & $26.07 \pm 2.92$ & $25.8 \pm 1.84$ & $26.07 \pm 1.64$ \\
\hline Crude protein & $20.14 \pm 1.42$ & $18.63 \pm 1.28$ & $19.21 \pm 1.16$ \\
\hline Ether extract & $4.86 \pm 0.64$ & $6.18 \pm 1.02^{\mathrm{a}}$ & $5.74 \pm 1.24$ \\
\hline Ash & $1.07 \pm 0.08$ & $0.98 \pm 0.10$ & $1.11 \pm 0.12$ \\
\hline
\end{tabular}

Data expressed as mean $\pm \mathrm{SD}$, standard deviation, $\mathrm{HFW}$, household food waste, superscript letter (a) indicates the significance $(\mathrm{P}>0.05)$.

Table 8: Effects of organic home underutilized resources inclusion on enzyme serum activities.

\begin{tabular}{lccc}
\hline Serum levels & $0 \% \mathrm{HFW}$ & $15 \% \mathrm{HFW}$ & $30 \%$ HFW \\
\hline AST (U/L) & $13.01 \pm 2.05$ & $13.80 \pm 4.34$ & $15.20 \pm 5.63$ \\
\hline ALT (U/L) & $5.20 \pm 3.78$ & $7.80 \pm 3.10$ & $8.80 \pm 2.90$ \\
\hline GGT(U/L) & $55.38 \pm 5.24$ & $62.46 \pm 6.04$ & $78.81 \pm 5.28^{\mathrm{a}}$ \\
\hline $\mathrm{TP}(\mathrm{g} / \mathrm{dl})$ & $6.88 \pm 1.26$ & $8.24 \pm 2.06$ & $6.60 \pm 3.52$ \\
\hline Creatinine (mg/dl) & $1.32 \pm 0.48$ & $1.24 \pm 0.87$ & $2.25 \pm 0.84$ \\
\hline
\end{tabular}

\section{DISCUSSION}

Our study aimed to investigate the bioavailability of HFW incorporation with lambs feed. In Egypt, HFW is composed mainly from breads, pea and beans. Thus, the DM of the collected food wastes was relatively higher in compared with (20\%) that reported by Ben (2001). This might be attributed to the higher amount of bread within HFW. Moreover, the higher energy and/or protein contents from the
HFW could provide competitive alternatives to more traditional energy and protein sources (Westendorf, 2000).

Minerals level seem to be high in HFW, however, it still below the dietary maximum tolerable limit for sheep Walker et al. (1997). Moreover, it can be accommodated in balanced diets Myer et al. (1994), Walker et al. (1998). The total aflatoxins'residues of HFW were within the permissible limits. HFW was 
freshly collected and efficiently dried Sugiura $e t$ al. (2009). Mycotoxins mostly have been plagued and mankind since the beginning of organized crop production and probably before. HFW incorporation in lamb's diet did not affect animals up to $30 \%$. In chicken, 30\% processed food wastes in conjunction with other essential ingredients achieved adequate results for body weight, feed consumption and feed conversion Normand (1996).

Wheat bran substitution with HFW reduced the cost of diets and improved profitability. Similarly, the average replacement price of HFW and substitution rates was significantly reduced the feed costs when compared with the average price of concentrates having equal amount of nutrients (as-fed basis) Oishi et al. (2011). Moreover, it is economically processed in duck rations Ben (2001). The economic estimate of $30 \%$ HFW incorporation in the lamb diets may lead to an appreciable reduction of the feeding cost per kilogram of body weight gain.

Energy and protein percentages in the diets, DM intake and physical characteristics of the diets were consistent with Burrin et al. (1990). In our study, HFW has a high nutritive value for sheep, which indicated with a higher EE digestibility in dietscontaining HFW. The growth performance and carcass characteristics obtained using diets containing HFW were found to be similar to those of the control group. HFW has no deleterious effect on meat chemical composition. In addition, the digestibility of primary nutrients in food waste must be $75 \%$ or greater to be an economical feed ingredient for inclusion in traditional diets Westendorf. (2000).

The biochemical results revealed normal serum levels of liver and kidneys enzymes of examined lambs. Unless lambs fed on $30 \%$ HFW had a higher serum GGT $(P<0.05)$. Higher serum levels of GGT could be indicated hepatobiliary disorders of sheep Braun et al. (2010). This result was consistent with pathological periportal oval cells proliferation, which representing a bipotential cell, and can be differentiated into either hepatocytes or bile duct epithelial cells. Furthermore, it has been shown clonogenic potential in vivo and in vitro. Oval cells are not normally involved in liver regeneration, due to the enormous replicative capacity of hepatocytes, but are induced to proliferate under conditions of severe liver injury when mature hepatocytes are overwhelmed or prevented from proliferating Fausto et al. (2003). It can be induced by chronic iron overloading of the rat supplemented with $2 \%$ iron containing diet over 3 months inducing marked oval cells proliferation Smith et al. (1996). Tubular degeneration of the kidneys was noticed, however there was non significant increase in kidney serum enzymes levels which could also indicates the possible toxic effect of $30 \% \mathrm{HFW}$ supplementation.
Analysis of 30\% HFWs demonstrated a higher dietary iron level which exceed the maximum tolerable limits in sheep which could be one of the inducible factors for oval cells induction in this group. In addition, the most of Egyptian crops and ecosystem reported a higher residue levels of heavy metals, which also support the higher levels in HFW Mansour et al. (2009).

\section{CONCLUSION}

Current result concluded that HFW was free from total aflatoxins. It was moderately high in protein, fat and minerals and may be used as a replacement of wheat bran in lamb diets. Incorporation of HFW in animal feed might be producible form the economic basis. However, the higher serum levels of GGT enzymes and oval cells induction at the 30\% supplementation of HFW with lambs feed embarrass the higher level incorporation of HFW as a substitutive source of animal feed.

\section{GRANT SUPPORT}

The study was funded by the Research Support Fund, Kafrelsheikh University.

\section{CONFLICT OF INTEREST}

The authors declare no conflict of interest.

\section{REFERENCES}

Abdullah, A.; Purchas R. and Davies A. (1998): Patterns of change with growth for muscularity and other composition characteristics of Southdown rams selected for high and low backfat depth. New Zealand journal of agricultural research. 41: 367-76.

AOAC.,(2005):Association of Official Analytical Chemists, Official methods of analysis of the AOAC international (18th ed.).

Ben, AA. (2001): Economic feasibility of processing food waste and incorporating products in least cost duck feeds.: Thesis, University of Mc Gill, Montreal Quebec, Canada.

Boccard, R.; Buchter, L.; Casteels, E.; Cosentino, E.; Dransfield, E. and Hood, D. (1981): Procedures for measuring meat quality characteristics in beef production experiments. Report of a working group in the Commission of the European Communities'(CEC) beef production research programme. Livestock Production Science. 8: 385-97.

Braun, J.; Trumel, C. and Bézille, P. (2010): Clinical biochemistry in sheep: A selected review. Small Ruminant Research. 92: 10-8.

Burrin, D.; Ferrell, C.; Britton, R. and Bauer, M. (1990): Level of nutrition and visceral organ size and metabolic activity in sheep. British Journal of Nutrition. 64: 439-48. 
Cao, Y.; Takahashi, T. and Horiguchi, K-i. (2009): Effects of addition of food by-products on the fermentation quality of a total mixed ration with whole crop rice and its digestibility, preference, and rumen fermentation in sheep. Animal feed science and technology. 151: $1-11$.

Communities, E. Council Directive 86/609/EEC of 24 November. (1986): on the approximation of laws, regulations and administrative provisions of the Member States regarding the protection of animals used for experimental and other scientific purposes. Official Journal of the European Union . p. pp. 1-28.

Fausto, N. and Campbell, JS. (2003): The role of hepatocytes and oval cells in liver regeneration and repopulation. Mechanisms of development. 120: 117-30.

Griffin, M. Sobal, J. and Lyson, TA. (2009): An analysis of a community food waste stream. Agriculture and Human Values. 26: 67-81.

Hall, KD.; Guo, J.; Dore, M. and Chow, CC. (2009): The progressive increase of food waste in America and its environmental impact. PloS one.4: e7940.

Kawashima T. (2004): The use of food waste as a protein source for animal feed-current status and technological development in Japan. Protein sources for the animal feed industry FAO Expert Consultation and Workshop, Bangkok, Thailand, 29 April-3 May 2002: Food and Agriculture Organization of the United Nations (FAO). p. 303-9.

Mansour, SA.; Belal, MH.; Abou-Arab, AA.; Ashour, HM. and Gad, MF. (2009): Evaluation of some pollutant levels in conventionally and organically farmed potato tubers and their risks to human health. Food and chemical toxicology. 47: 615-24.

Myer, R.; DeBusk, T.; Brendemuhl, J. and Rivas M. (1994): Initial assessment of dehydrated edible restaurant waste (DERW) as a potential feedstuff for swine. Res Rep A1-1994-2 College of Agriculture Florida Agricultural Experiment Station University of Florida Gainesville, FL.

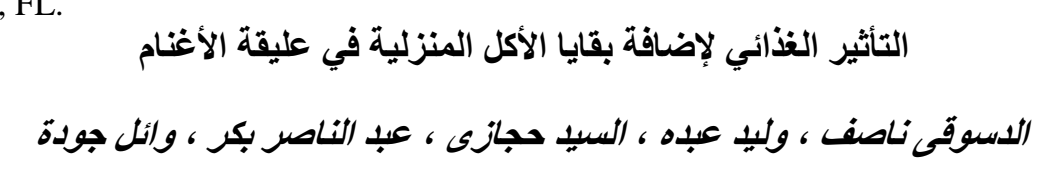

Email: waliedsobhy@yahoo.com
Normand (1996): Duck meat production based on the recycling of agro-industrial food waste in the province of Que'bec.: Montre'al, QC, Canada, McGill University.

NRC (1985): Nutrient Requirements of Sheep. Nutr. Req. of Domest. Animals (6th rev. ed) ed: Natl. Academy Press, Washington, DC, pp 99.

Oishi, K.; Kumagai, H. and Hirooka, H. (2011): Application of the modified feed formulation to optimize economic and environmental criteria in beef cattle fattening systems with food by-products. Animal Feed Science and Technology. 165: 38-50.

Okazaki, WK.; Turn, SQ. and Flachsbart, PG. (2008): Characterization of food waste generators: a Hawaii case study. Waste Manag. 28: 2483-94.

Oreopoulou, V. and Russ, W. (2007): Utilization of by-products and treatment of waste in the food industry: Springer.

Smith, P. and Yeoh, G. (1996): Chronic iron overload in rats induces oval cells in the liver. The American journal of pathology. 149: 389.

Sugiura, K.; Yamatani, S.; Watahara, M. and Onodera, T. (2009): Ecofeed, animal feed produced from recycled food waste. Veterinaria italiana. 45: 397-404.

Summers, J.; Macleod, G. and Warner, W. (1980): Chemical composition of culinary wastes and their potential as a feed for ruminants. Animal Feed Science and Technology. 5: 205-14.

Walker, P.; Hoelting, F. and Wertz, A. (1998): Fresh pulped food waste replaces supplemental protein and a portion of the dietary energy in total mixed rations for beef cows. The Professional Animal Scientist. 14: 207-16.

Walker, P.; Wertz, S. and Marten, T. (1997): Selected fractionate composition and digestibility of an extruded diet containing food waste fed to sheep. J Anim Sci. 75: 253.

Westendorf, ML. (2000): Food waste to animal feed: John Wiley and Sons.

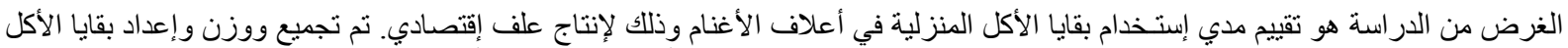

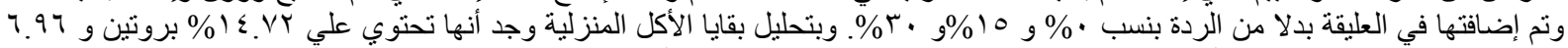

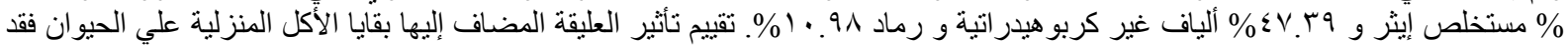

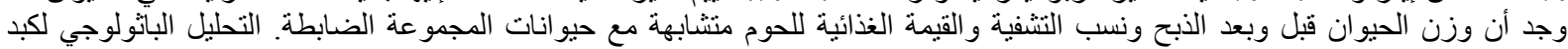

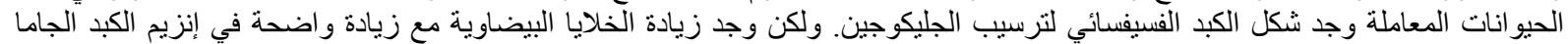

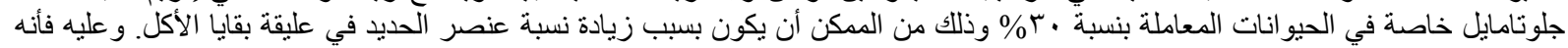

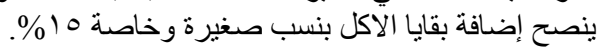

